\title{
$\beta$-Sitosterol Compound from Dichloromethane Extracts of Kalanchoe tomentosa (Crassulacea) Leaves and Inhibition of $\alpha$-amilase Activity
}

\author{
Lilis Siti Aisyah*, Faridia Puspita, Yenny Febriani Yun, Adelia Ilfani \\ Chemistry Department, Faculty of Science and Informatics, Jenderal Achmad Yani University \\ Jl. Ter. Jend. Sudirman PO BOX 148 Cimahi, 40526, Indonesia \\ *Corresponding author: lies.syarifudin69@gmail.com
}

Received: December 2020; Revision: February 2021; Accepted: July 2021; Available online: July 2021

\begin{abstract}
Kalanchoe tomentosa is one of the plants of the Crassulaceae tribe that can lower blood sugar and contains compounds of terpenoids, flavonoids, alkaloids, saponins, tannins, fatty acids, steroids, and triterpenoids. This study aims to isolate and identify chemical compounds from dichloromethane extract of Kalanchoe tomentosa leaves, as well as to test the inhibitory activity of the $\alpha$-amylase enzyme. Extraction was carried out by maceration using dichloromethane as a solvent, then dichloromethane extract was purified using column chromatography, the pure isolate was obtained in the form of white powder, and an inhibition test was carried out against the $\alpha$-amylase enzyme. The thin layer chromatography data of pure isolates compared to pure $\beta$ sitosterol are similar. Based on the research data, it can be concluded that the chemical structure of the pure isolate is $\beta$-sitosterol, the methylene chloride extract of $\mathrm{K}$. tomentosa leaves has an inhibitory activity against the $\alpha$-amylase enzyme with an inhibition value of $65 \%$. This value is greater than the positive control of acarbose which only has $37 \%$ inhibition and $\beta$-sitosterol compound by $6.7 \%$. This value is smaller when compared to the control of acarbose at the same concentration which obtained $5 \%$ inhibition.
\end{abstract}

Keywords: $\alpha$-amylase, $\beta$-sitosterol , Crassulaceae, enzyme, Kalanchoe tomentosa.

DOI: $10.15408 / j k v . v 7 i 1.18443$

\section{INTRODUCTION}

Diabetes mellitus (DM) is a metabolic disease that has become a serious problem in the world. According to the International Diabetes Federation (IDF, 2013), Indonesia is included in the top 10 countries with the highest diabetes cases, to be precise at number 7 with 10 million diabetes cases. Up until now, diabetes has still become one of the biggest causes of death in Indonesia. This was proved by the Data Sample Registration Survey in 2014 where diabetes is the 3rd cause of death in Indonesia after stroke and coronary heart disease (Kemenkes, 2014). Diabetes mellitus cannot be cured, but diabetes mellitus can be controlled. Treatment given to DM patients aims to normalize blood sugar levels and prevent complications. The patient's blood sugar level will be kept in the range of 80-130 $\mathrm{mg} / \mathrm{dL}$ before meals, and below $180 \mathrm{mg} / \mathrm{dL}$ two hours after eating (Widodo, 2014). Controlling postprandial glucose levels is an important strategy in preventing type 2 diabetes, so that a therapeutic approach can be taken by delaying glucose absorption by inhibiting carbohydrate hydrolysis enzymes, such as $\alpha$-glucosidase in the digestive organs (Kim et al., 2005). Some of the inhibitors that have been used clinically are acarbose and miglitol which inhibit glycosidases such as $\alpha$ glucosidase and $\alpha$-amylase. However, many hypoglycemic agents have limitations since they cause side effects and increase diabetes complications. The main side effects of $\alpha$ glucosidase inhibitors on the gastrointestinal tract including bloating, nausea, diarrhea, and fluctuation. Natural $\alpha$-glucosidase inhibitors derived from natural ingredients can be used as a therapeutic approach to treat postprandial hyperglycemia because they have low side effects and are more affordable than synthetic anti-hyperglycemic drugs (Li et al., 2005).

Based on this information, researchers are encouraged to develop natural herbal 
medicines to treat diabetes mellitus. More than 400 types of plants have been shown to have hypoglycemic activity because they contain compounds that have anti-diabetic properties such as polysaccharides, proteins, flavonoids, alkaloids, terpenoids and steroids (Kim et al., 2006).

One of the plants that has anti-diabetic properties is the Kalanchoe plant. Kalanchoe is known as a medicinal plant in traditional medicine. The Kalanchoe genus is reported to have contained bufadienolides, triterpenoids, flavonoids, triterpenoids and steroids (Saleh $e t$ al., 2014).

An amount of research has been conducted upon the Kalanchoe genus, but not much research on Kalanchoe tomentosa was conducted. Aisyah et al, (2017) have reported a flavonoid that has cytotoxic activity against P-388 murine leukemia cells from ethyl extracts of $K$. tomentosa. Saleh et al, (2014) have reported antioxidant activity of various $K$. tomentosa extracts, where the extracts were methylene chloride extract, ethyl acetate extract, and $n$-butanol extract with the $\mathrm{IC}_{50}$ value of $71.3 \mu \mathrm{g} / \mathrm{mL}, 35.4 \mu \mathrm{g} / \mathrm{mL}, 99.3 \mu \mathrm{g} /$ $\mathrm{mL}$, respectively.

Based on the report, it is necessary to do further research on $K$. tomentosa plants considering that these plants have never been tested for hypoglycemia activity. The objective of this study was to determine the inhibitory activity of the $\alpha$-amylase enzyme from $\beta$ sitosterol compounds found in $K$. tomentosa.

\section{MATERIALS AND METHODS Instruments}

Laboratory glassware, a set of maceration tools, Blender (Philips HR 2102), chamber, capillary tube, vials, analytical balance (Mettler AE 260 DeltaRage), tweezers, ultraviolet lamp (Vilber Lourmat VL-8.LC), rotary evaporator (Heidolph Laborota 4000), a set of chromatography tools with vacuum liquid, infrared spectrophotometer (Shimadzu Prestige-21), ${ }^{1} \mathrm{H}-\mathrm{NMR}$ spectrometer (JEOL JNM-ECZ500R/S1 $500 \mathrm{MHz}$ )

\section{Materials}

Kalanchoe tomentosa leaves, distilled water, acetone $\left(\mathrm{CH}_{3} \mathrm{COCH}_{3}\right)$, ethyl acetate $\left(\mathrm{CH}_{3} \mathrm{COOC}_{2} \mathrm{H}_{5}\right)$, dichloromethane $\left(\mathrm{CH}_{2} \mathrm{Cl}_{2}\right)$, methanol $\left(\mathrm{CH}_{3} \mathrm{OH}\right), n$-hexane $\left(\mathrm{C}_{6} \mathrm{H}_{14}\right)$, chloroform $\left(\mathrm{CHCl}_{3}\right)$ pa, $\mathrm{F}_{254}$ Thin Layer Chromatography plate (Merck), 60 (0.2- 0.5 $\mathrm{mm}$ ) silica gel (Merck), $60 \mathrm{G}$ silica gel (Merck), amylase enzyme, phosphate buffer $(\mathrm{pH} 7)$

\section{Extraction and isolation of compounds}

$20 \mathrm{~kg}$ of fresh $K$. tomentosa leaves were extracted using $n$-hexane solvent for 24 hours (repetition upon maceration was conducted until the filtrate is colorless, proved by TLC control). The residue then filtered and reextracted by maceration using methylene chloride for 24 hours. The filtrate further collected and concentrated using a rotary evaporator to produce a dark green $(35 \mathrm{~g})$ methylene chloride extract. Next, the extract was separated by Vacuum Liquid Chromatography (KCV) with $\mathrm{G}_{60}$ silica gel using an elution gradient of $n$-hexane-EtOAc which produced 10 fractions. White needle crystals $(8 \mathrm{mg})$ in fraction 5 were obtained which were then recrystallized with $n$-hexane to remove the impurities. The TLC analysis was carried out to determine its purity and will be compared with pure $\beta$-sitosterol compounds using $n$-hexane-EtOAc eluent.

\section{$\alpha$-amylase activity using the Fuwa method} (Fuwa et al., 1954; Bhutkar and Bhise, 2012)

$1 \mathrm{~mL}$ of water was added with $1 \mathrm{~mL}$ $(1 \% \mathrm{w} / \mathrm{v})$ of starch solution, then pre-incubated with $1 \mathrm{~mL}$ of $\alpha$-amylase enzyme (100x dilution). The mixture was incubated at $37{ }^{\circ} \mathrm{C}$ for 10 minutes. The reaction was stopped by adding $1 \mathrm{~mL}$ of Nelson's reagent. The mixture then heated in boiling water for 20 minutes and cooled at $25{ }^{\circ} \mathrm{C}$ with the addition of $1 \mathrm{~mL}$ of arsenomolybdate and $7 \mathrm{~mL}$ of distilled water. Blanks were prepared without extract and without $\alpha$-amylase enzyme in phosphate buffer $\mathrm{pH}$ 7. Absorbance measurements were measured at a wavelength of $600 \mathrm{~nm}$. The standard curve is derived from starch as maltose equivalent. Acarbose (anti-diabetic drug) was used as a positive control (1 tablet dose of $50 \mathrm{mg}$ dissolved in $10 \mathrm{~mL}$ of distilled water), also methylene chloride and beta sitosterol were used.

\section{RESULT AND DISCUSSION}

White color needle crystal isolate was obtained from the isolation process. The isolate dissolved in polar solvents and A comparison of TLC analysis of compund 1 with $\beta$ sitosterol from the plant Kalanchoe blossfeldiana showed that $\mathrm{Rf}$ value and spots 
obtained were very similar. Therefore, isolate was identified as $\beta$-sitosterol (Fig 1). Isolated crystal needles were observed to melted at $145-148^{\circ} \mathrm{C}$.

Based on the results of TLC, IR and ${ }^{1} \mathrm{H}-$ NMR, isolate 1 is similar with the pure $\beta$ sitosterol compound from Kalanchoe blossfeldiana plant (figure 1). FTIR Analysis: The IR spectrum (Fig. 2) showed absorption peaks at $3415.93 \mathrm{~cm}^{-1}$ (O-H stretching.); $2945.30 \mathrm{~cm}^{-1}$ and $2866.22 \mathrm{~cm}^{-1}$ (aliphatic $\mathrm{C}-\mathrm{H}$ stretching); $1649.14 \mathrm{~cm}^{-1} \quad(\mathrm{C}=\mathrm{C}$ absorption peak). Other absorption peaks include 1454.33
$\mathrm{cm}^{-1}\left(\mathrm{CH}_{2}\right) ; 1371.39 \mathrm{~cm}^{-1}$ (OH def), 1047.35 $\mathrm{cm}^{-1}$ (cycloalkane).

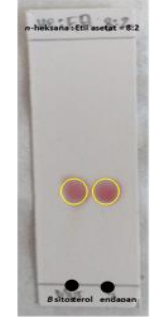

(a)

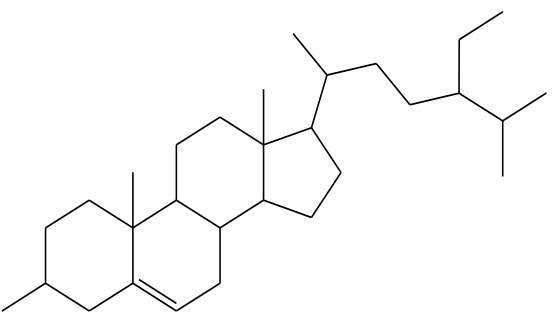

(b)
Figure 1. Comparison of standard $\beta$ sitosterol with precipitated compund 1 (a) and Chemical Structure of $\beta$-sitosterol compound (b)

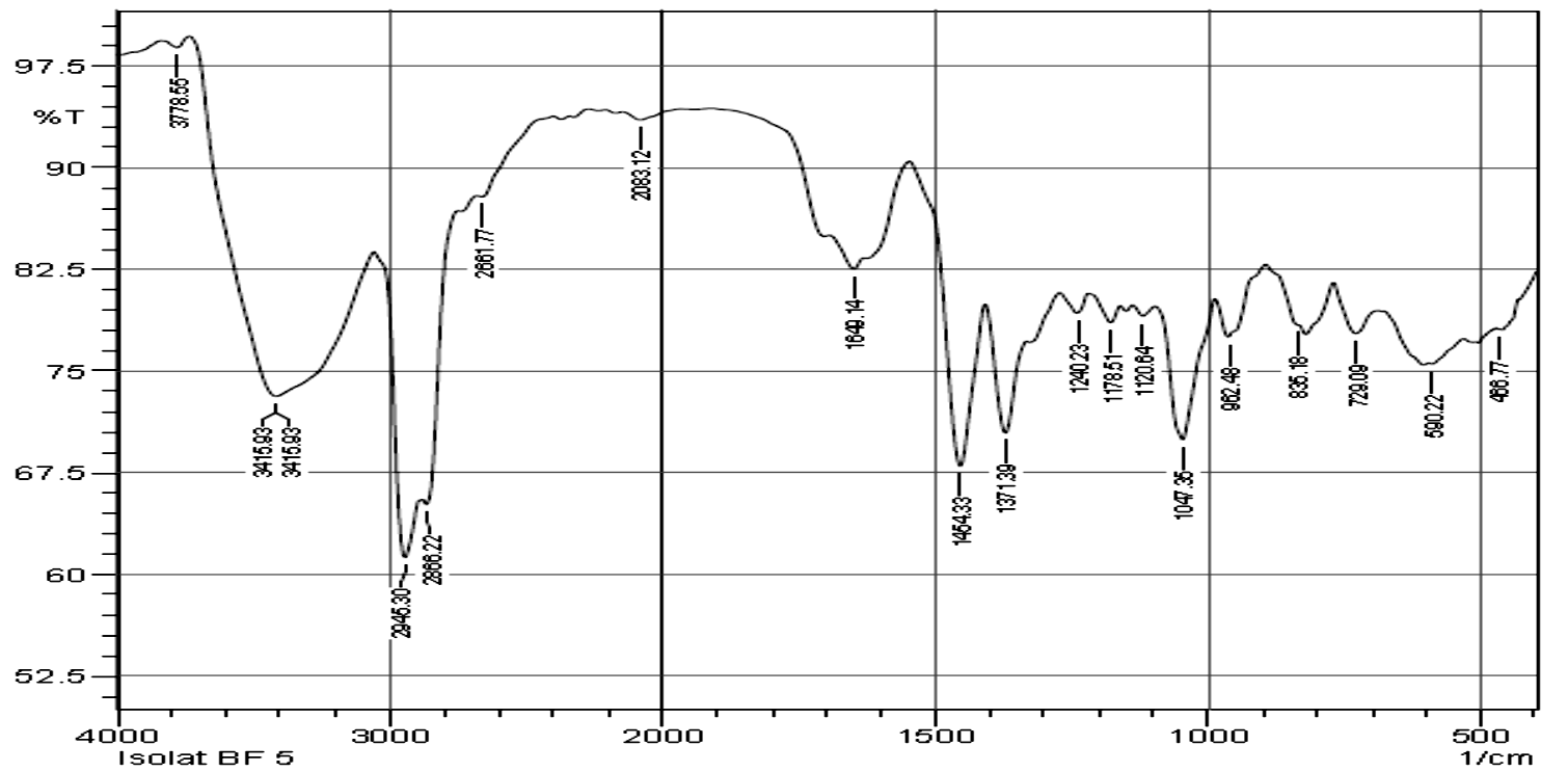

Figure 2. FTIR spectra of compound 1

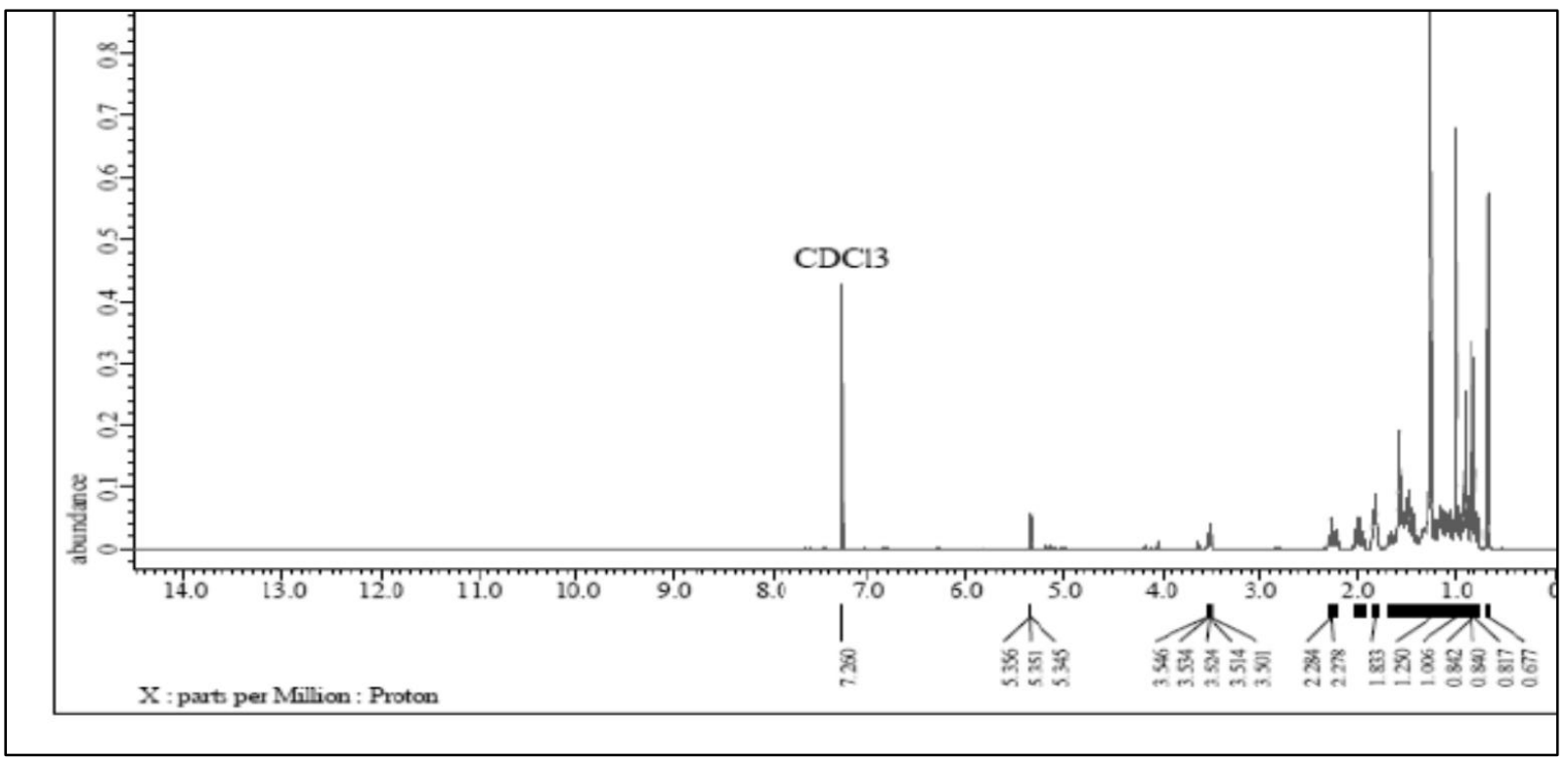

Figure 3. Chemical shift of the proton compound 1 
Table 1. Proton chemical shift of the compound 1 and $\beta$-sitosterol

\begin{tabular}{|c|c|c|}
\hline $\mathbf{C}$ & $\delta H(\Sigma H, ~ m, J ~ H z)$ Compound $1 * *)$ & $\delta H(\Sigma H, ~ m, J ~ H z) \beta$-sitosterol *) Yun, 2015 \\
\hline 1 & $1.05: 1.02(2 \mathrm{H}, d d, 10.5: 5.5)$ & $1.07: 1.02(2 \mathrm{H}, d d, 10.5: 5.5)$ \\
\hline 2 & $1.44: 1.47(2 \mathrm{H}, t d, 9.5: 6.0)$ & $1.44: 1.48(2 \mathrm{H}, t d, 9.5: 6.0)$ \\
\hline 3 & $3.49(1 \mathrm{H}, m)$ & $3.51(1 \mathrm{H}, m)$ \\
\hline 4 & $2.23: 2.31(2 \mathrm{H}, m)$ & $2.22: 2.29(2 \mathrm{H}, m)$ \\
\hline 5 & - & - \\
\hline 6 & $5.35(1 \mathrm{H}, t, 2.5)$ & $5.35(1 \mathrm{H}, b r)$ \\
\hline 7 & $1.85: 2.01(2 \mathrm{H}, \mathrm{dt}, 5.6: 8.5)$ & $1.85: 2.01(2 \mathrm{H}, \mathrm{dt}, 5.6: 8.5)$ \\
\hline 8 & $1.60(1 \mathrm{H}, m)$ & $1.57(1 \mathrm{H}, m)$ \\
\hline 9 & $0.93(1 \mathrm{H}, m)$ & $0.93(1 \mathrm{H}, m)$ \\
\hline 10 & - & - \\
\hline 11 & $1.42: 1.47(2 \mathrm{H}, m)$ & $1.42: 1.49(2 \mathrm{H}, m)$ \\
\hline 12 & $1.15: 1.95(2 \mathrm{H}, \mathrm{d}, 5.6)$ & $1.15: 1.98(2 \mathrm{H}, \mathrm{d}, 5.6)$ \\
\hline 13 & - & - \\
\hline 14 & $1.01(1 \mathrm{H}, m)$ & $1.00(1 \mathrm{H}, m)$ \\
\hline 15 & $1.63(2 \mathrm{H}, \mathrm{m})$ & $1.57(2 \mathrm{H}, m)$ \\
\hline 16 & $1.95(2 \mathrm{H}, \mathrm{m})$ & $1.84(2 \mathrm{H}, m)$ \\
\hline 17 & $1.09(1 \mathrm{H}, d t, 5.2: 8.5)$ & $1.09(1 \mathrm{H}, d t, 5.2: 8.5)$ \\
\hline 18 & $0.68(3 \mathrm{H}, s)$ & $0.68(3 \mathrm{H}, s)$ \\
\hline 19 & $1.01(3 \mathrm{H}, s)$ & $1.01(3 \mathrm{H}, s)$ \\
\hline 20 & $1.31(1 \mathrm{H}, m)$ & $1.36(1 \mathrm{H}, m)$ \\
\hline 21 & $0.69(3 \mathrm{H}, d: 6.1)$ & $0.92(3 \mathrm{H}, d, 6.1)$ \\
\hline 22 & $1.31(2 \mathrm{H}, m)$ & $1.38(2 \mathrm{H}, m)$ \\
\hline 23 & $1.50(2 \mathrm{H}, m)$ & $1.54(2 \mathrm{H}, m)$ \\
\hline 24 & $0.94(1 \mathrm{H}, m)$ & $0.93(1 \mathrm{H}, m)$ \\
\hline 25 & $1.66(1 \mathrm{H}, m)$ & $1.66(1 \mathrm{H}, m)$ \\
\hline 26 & $0.84(3 \mathrm{H}, d, 6.2)$ & $0.84(3 \mathrm{H}, d, 6.2)$ \\
\hline 27 & $0.92(3 \mathrm{H}, d, 6.7)$ & $0.92(3 \mathrm{H}, d, 6.7)$ \\
\hline 28 & $1.25(2 \mathrm{H}, m)$ & $1.26(2 \mathrm{H}, m)$ \\
\hline 29 & $0.82(3 \mathrm{H}, s)$ & $0.83(3 \mathrm{H}, s)$ \\
\hline
\end{tabular}

$* *{ }^{1} \mathrm{H}-\mathrm{NMR} \mathrm{CDCl}_{3}, 500 \mathrm{MHz}$

${ }^{* 1} \mathrm{H}-\mathrm{NMR}$ aseton- $d 6,500 \mathrm{MHz}$

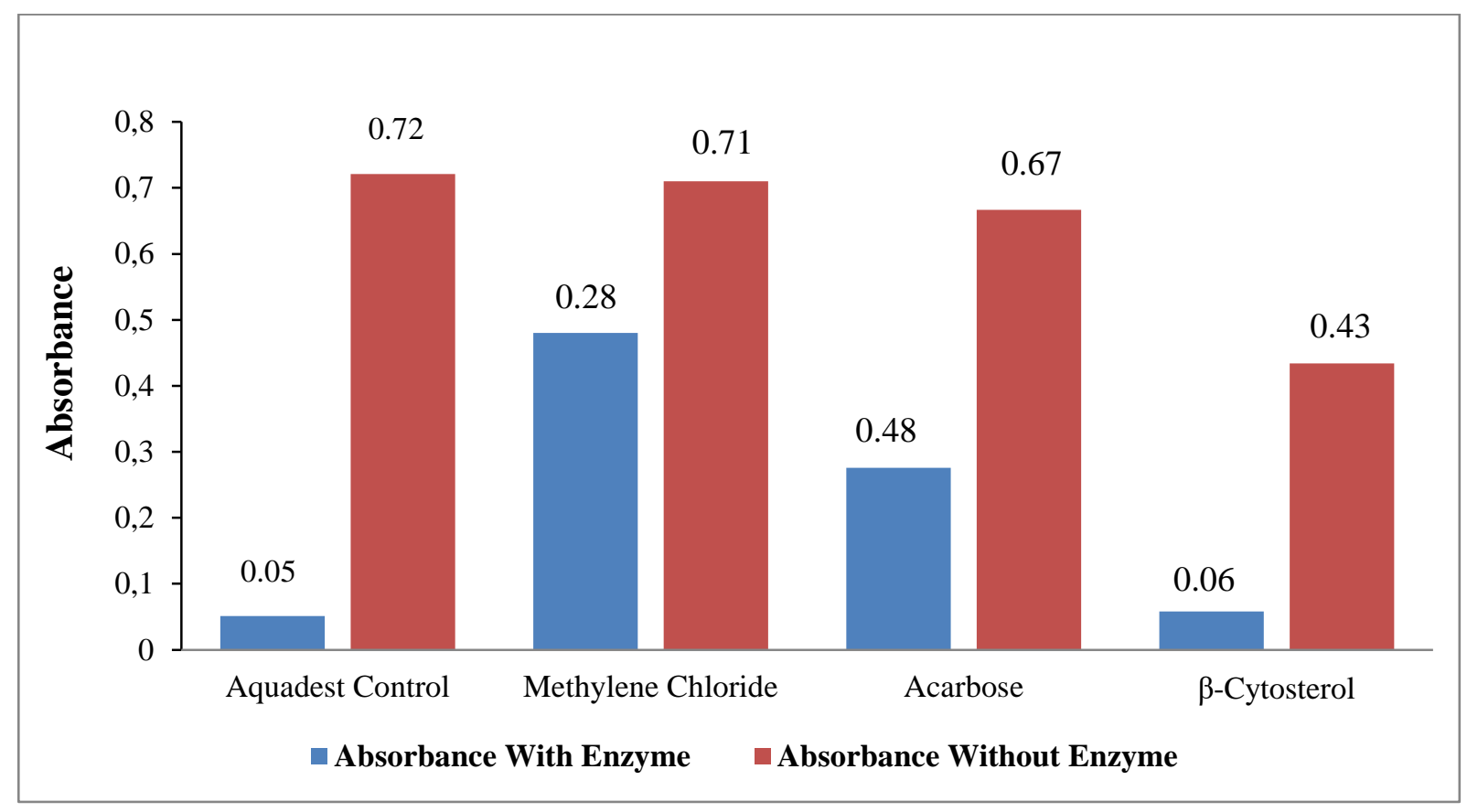

Figure 4. Graph of the absorbance value of the sample 


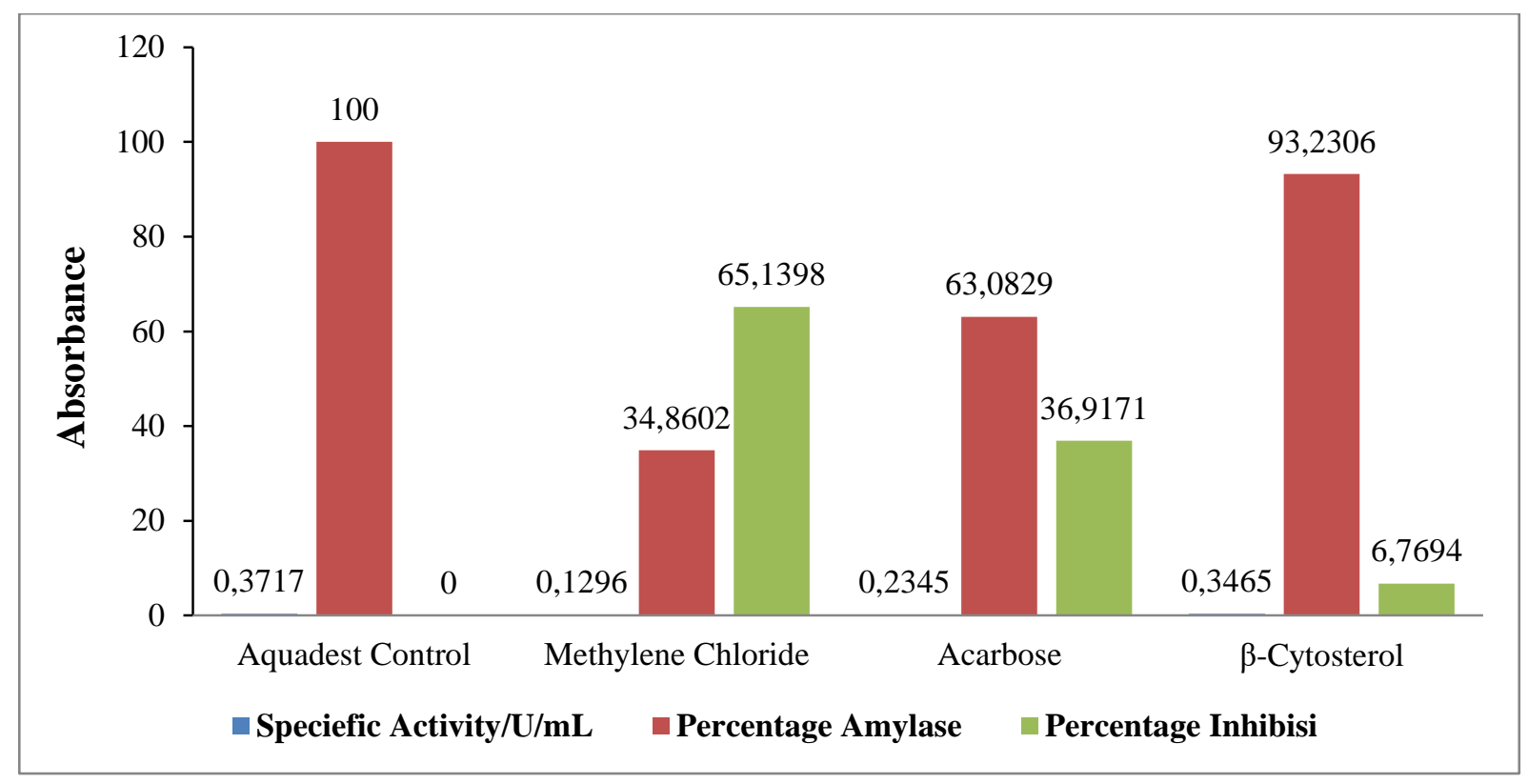

Figure 5. Graph of $\alpha$-amylase enzyme inhibition value by each sample

Figure 4 showed that the absorbance without the presence of enzymes is higher than the absorbance with the presence of enzymes. This occurred after the addition of the enzyme. The extract able to inhibit the hydrolysis of starch when enzymes are added. Starch or amylose will be easier to hydrolyze into simple molecules. The nature of the enzyme is the catalyst which can speed up the reaction without reacting. The activity of the $\alpha$-amylase enzyme can be determined based on the absorbance value obtained. The $\alpha$-amylase enzyme activity test was carried out to determine the ability of the $\alpha$-amylase enzyme to hydrolyze starch into simple sugars. According to Saleh et al. (2014), the final product of $\alpha$-amylase is oligosaccharide of varying length and $\alpha$-configuration and $\alpha$-limit dexrine which consists of a mixture of maltose, maltotriose, and oligosaccharide branches (6-8 glucose units) which contain $\alpha-1-4$ and $\alpha-1-6$.

The activity of the $\alpha$-amylase enzyme was observed as a decrease in the intensity of the blue color in the iodine-starch complex due to reduced starch substrate due to hydrolysis carried out by the $\alpha$-amylase enzyme. The blue color of the iodine-starch complex can be observed by spectrophotometer. The darker blue color shows the excess amount of starch. This occurred due to the formation of iodine and starch complexes where iodine is trapped in the helical structure of starch (amylose).

Figure 5 showed the specific activity of the enzyme in determining the inhibition percentage of each extract. An enzyme activity unit is the amount of enzyme that causes a change of $1 \mu \mathrm{mol}$ (10-6) of the substrate per minute at $25{ }^{\circ} \mathrm{C}$ under optimum conditions. The specific activity is the number of enzyme activity units per milligram of protein (Saleh $e t$ $a l ., 2014)$. In the control test for inhibition of the $\alpha$-amylase enzyme, acarbose was used since acarbose is an antidiabetic drug used to inhibit the action of the $\alpha$-amylase enzyme, inhibits carbohydrate processes in the digestive system, and reduces glucose absorption thereby preventing postprandial plasma glucose rise (Saleh et al., 2014). This medicine helps lower blood sugar levels after eating. According to Andayani et al., (2009), therapeutic combination of sulfonylurea, metformin, and acarbose in type 2 diabetes mellitus patients whose blood glucose control is poor, can lead to the risk of developing complications and drug side effects.

Testing the sample with the addition of methylene chloride extract with a concentration of $5 \%$ gave an inhibition value of the amylase enzyme of $65 \%$, while the sample added with the pure compound $\beta$ sitosterol with the same concentration gave an inhibition value of $6.7 \%$. When compared with the control drug, acarbose, at the same concentration with $37 \%$ inhibition of methylene chloride extract had a greater inhibitory value, while the pure compound $\beta$ sitosterol had a smaller inhibition value. According to Saifudin, (2014), crude extracts 
show an active or more active effect with positive control, often semi-pure ingredients have a loss of pharmacological effects. This is due to the synergistic effect, in which the presence of one or several compounds causing the strengthening of the active effect, where a single pure compound has no effect or is very weak. Separation causes weak activity or no activity. The percentage of inhibition of pure $\alpha$-sitosterol at a concentration of $5 \%$ was not too high, which was only $6.7 \%$. It was caused by the structure of the $\beta$-sitosterol compound where there are not many $-\mathrm{OH}$ groups present. The $-\mathrm{OH}$ group is able to act as a compound that can neutralize free radicals, thus preventing damage to pancreatic beta cells that produced insulin.

\section{CONCLUSION}

Based on the results of the research, it can be concluded that the isolate was obtained as a white powder with the form of a needle. It is assumed that isolate 1 is a $\beta$-sitosterol compound. The methylene chloride extract of $K$. tomentosa leaves has inhibitory activity against the $\alpha$-amylase enzyme with an inhibition value of $65 \%$. This value is greater than the positive control of acarbose which only has $37 \%$ inhibition and $\beta$-sitosterol compounds of $6.7 \%$. This value is smaller compared with the acarbose at the same concentration of $5 \%$.

\section{ACKNOWLEDGEMENT}

Thanks to LPPM Unjani for funding this research and Unjani Chemical Laboratory for facilitating the research.

\section{REFERENCES}

Aisyah LS, Yun YF, Herlina T, Julaeha E, Zainuddin A, Nurfarida I, Hidayat AT, Supratman U, Shiono Y. 2017. Flavonoid compounds from the leaves of Kalanchoe prolifera and their cytotoxic activity against P-388 murine leukimia cells. Natural Product Sciences. 23(2): 139-145.

Andayani TM, Ibrahim MI, Asdie AH. 2009. Pengaruh kombinasi terapi sulfonilurea, metformin, dan acarbose pada pasien diabetes mellitus tipe 2. Majalah Farmasi Indonesia. 20(4): $224-230$.
Bhutkar MA, Bhise SB. 2012. In vitro assay of alpha amylase inhibitory activity of some indigenous plants. Int. J. Chem. Sci. 10(1): 457-462.

Fuwa H. 1954. A new method for microdetermination of amylase activity by the use of amylose as the substrate. Journal of Biological Chemistry. 41(5): 583-603.

Howard W. 2015. Pengujian Aktivitas Enzim $\alpha$ Amilase. Bandung (ID): ITB.

[IDF] International Diabetes Federation. 2013. IDF Diabetes

Kementrian Kesehatan RI. Badan Penelitian dan Pengembangan. 2014. Jakarta (ID): Riskesdas.

Kim YM, Jeong YK, Wang MH, Lee WY, Rhee HI. 2005. inhibitory eff ect of pine extract on alpha glucosidase activity and postprandial hyperglycemia. Nutrition. 21: 756-61.

Kim JS, Ju JB, Choi CW, Kim SC. 2006. Hypoglycemic and antihyperlipidemic effect of korean medicinal plants in alloxan induced diabetic rats. Am $J$ of Biochemistry and Biotecnology. 2(4): $154-160$.

Li Y, Wen S, Prasad BK, Peng G, Qian GL, Yamahara J, Roufogalis BD. 2005. Punica granatum flower extract, a poten $\alpha$ Glucosidase inhibitor, improves postprandial hyperglikemia in zuker diabetic fatty rats. Etnopharm. 2005 (99): 239-244.

Saleh MM, Ghoneim MM, Kottb S, El-Hela AA. 2014. Biologically active secondary metabolites from Kalanchoe tomentosa. Journal of Biomedical and Pharmaceutical Research. 3(6): 136-140.

Saifudin A. 2014, Senyawa Alam Metabolit Sekunder: Teori, Konsep, dan Teknik Pemurnian, Edisi 1., Deepublish, Yogyakarta

Widodo Y. 2014. Pemantauan penderita diabetes. Jurnal Ilmiah Kedokteran. 3(2): 55-69

Yun YF. 2015, Metabolit Sekunder dari Beberapa Tumbuhan Kalanchoe yang Tumbuh di Indonesia dan Aktivitas Sitotoksiknya terhadap Sel Murin Leukimia P-388, Disertasi, Departemen Kimia, Universitas Padjajaran, Bandung. 